\title{
NPR1 Gene
}

National Cancer Institute

\section{Source}

National Cancer Institute. NPR1 Gene. NCI Thesaurus. Code C112513.

This gene plays a role in lig and-dependent cyclic GMP synthesis. 